Tersedia Online di http://journal2.um.ac.id/index.php/wsd/

ISSN 0854-8293 (cetak)

\title{
PERKEMBANGAN FISIK MOTORIK DAN PERSEPTUAL SERTA IMPLIKASINYA PADA PEMBELAJARAN DI SEKOLAH DASAR
}

\author{
Tri Murti \\ PP3 Jl Ir Soekarno 1 Blitar, Universitas Negeri Malang \\ e-mail :dratrimurti@gmail.com
}

\begin{abstract}
Abstrak: Perkembangan fisik adalah perkembangan yang berkaitan dengan tinggi dan berat, serta bentuk tubuh, juga perkembangan otak. Perkembangan motorik, berkaitan dengan ketrampilan gerak. Perkembangan perseptual adalah merupakan kemampuan anak mengenal terhadap lingkungan. Implementasi dalam proses pembelajaran di SD antara lain : (1) Pembelajaran di lakukan secara langsung (2) melalui permainan-permainan yang sesuai dengan perkembangan anak, (3) pembelajaran yang dapat dilihat, didengar dan dirasa oleh indra yang lain. Agar informasi dapat diserap oleh anak dan difahami. Anak menjadi senang sehingga tujuan pembelajaran menjadi tercapai.
\end{abstract}

Kata kunci : perkembangan fisik, motorik, sekolah dasar

Undang-Undang RI Nomor 20 Tahun 2003, menyatakan bahwa Pendidikan adalah Usaha sadar dan terencana untuk mewujudkan suasana belajar dan proses pembelajaran agar peserta didik secara aktif mengembangkan potensi dirinya untuk memiliki kekuatan spiritual keagamaan, pengendalian diri, kepribadian, kecerdasan, akhlak mulia, serta keterampilan yang diperlukan dirinya, Masyarakat, bangsa dan negara. Pernyataan tersebut mengisyaratkan bahwa dalam proses pembelajaran guru hendaknya menciptakan suasana menyenangkan, mengaktifkan siswa dalam mengembangkan potensi/kemampuannya.

Siswa senang dan aktif dalam belajar, serta dapat mengembangkan potensinya apabila guru dapat merancang, dan membelajarkan siswa sesuai dengan karakteristik perkembangan siswa. Perkembangan tersebut diantaranya adalah perkembangan fisik dan motorik serta perseptual. Perkembangan fisik berkaitan dengan tinggi dan berat badan, proporsi dan bentuk tubuh, sedangkan perkembangan motorik meliputi, kemampuan siswa melakukan gerak untuk beraktitifitas dalam belajar maupun dalam kehidupan sehari-hari. Sedangkan perkembangan perseptual siswa berkaitan dengan kemampuan siswa mengenal terhadap lingkungan.

Perkembangan fisik adalah perkembangan yang berkaitan dengan tinggi dan berat badan, serta bentuk tubuh, juga perkembangan otak (Wahab 1998). Pada usia sekolah dasar, berbeda pada usia-usia sebelumnya. Usia 6-12 tahun perkembangan fisik relatif lebih lambat dan lebih konsisten. Laju perkembangan seperti ini berlangsung sampai terjadinya perubahan- perubahan besar pada awal masa pubertas.

Perkembangan porporsi atau bentuk tubuh pada awal masuk sekolah dasar umumnya masih belum seimbang. Kekurangan seimbangan ini dapat diamati pada bagian kepala, badan dan kaki. Kepala masih terlalu besar bila dibandingkan dengan anggota tubuh lainnya seiring berjalannya waktu lambat laun anggota tubuh yang kurang seimbang menjadi berkembang secara harmonis. Sheldon 
(dalam Hurlock, 1980) mengemukakan ada tiga kemungkinan bentuk primer tubuh siswa sekolah dasar adalah ; (a) endomorph, yakni yang tampak dari luar dan berbadan besar ; (b) mesomorph yang kelihatan kokoh, kuat dan kekar ; (c) ectomorph yang tampak jangkung, dada pipih, lemah dan seperti tak berotot.

Pertumbuhan otak dan sistem syaraf merupakan salah satu aspek yang terpenting dalam perkembangan individu. Pertumbuhan otak dan kepala jauh lebih cepat dibandingkan bagian-bagian tubuh lainnya. Pada usia tiga tahun saja, pertumbuhan otak anak sudah mencapai dua pertiga dari ukuran otak orang dewasa, dan menjelang umur lima tahun, ukuran otak anak sudah mencapai kurang lebih $90 \%$ dari ukuran otak orang dewasa.

Selaras dengan pertumbuhan otak pada diri anak, maka pertumbuhan syaraf otak juga semakin berkembang dengan sempurna sehingga mempengaruhi terhadap kematangan kognisi/berfikir anak. Namun kematangan otak ini tidak dapat berkembang tanpa adanya rangsangan-rangsangan dari luar. Respon anak terhadap rangsangan dari luarpun diperlukan demi terwujudnya kesempurnaan perkembangan kognisi anak. Dengan demikian aktivitas motorik anak diperlukan untuk mengoptimalkan perkembangan kognitif.

Perkembangan motorik, berkaitan dengan keterampilan gerak pada usia sekolah dasar, motorik anak sudah lebih halus dan lebih terkoordinasi dari masa sebelumnya. Pada usia 10 - 11 tahun, anak-anak lazimnya sudah mampu melakukan berbagai jenis kegiatan olahraga seperti; lari, mendaki, lompat tali, berenang dan mengendarai sepeda. Bagi anak penguasaan ketrampilan-ketrampilan fisik dapat merupakan sumber kesenangan dan prestasi, Anak menjadi senang karena dengan menguasai berbagai keterampilan fisik ia dapat bermain dan melakukan berbagai aktifitas yang diinginkan.

Seiring dengan perkembangan fisik dan motorik munculah perkembangan perseptual anak. Aktifitas perseptual pada dasarnya mer- upakan proses pengenalan individu terhadap lingkungan. Semua informasi tentang lingkungan sampai kepada individu melalui alatalat indra yang kemudian diteruskan melalui syaraf sensoris ke bagian otak. Informasi tentang obyek penglihatan diterima melalui indra mata. Informasi tentang obyek pendengaran diketahui melalui indra telinga, obyek sentuhan melalui kulit, obyek penciuman melalui indra hidung. Oleh sebab itu memahami tentang perkembangan fisik, motorik danperseptual merupakan hal yang penting, terutama bagi seorang guru.

Berdasarkan uraian diatas pada artikel ini akan dibahas tentang perkembangan fisik, motorik dan perseptual anak sekolah dasar, serta implikasinya dalam proses pembelajaran. Harapanya guru dapat membelajarkan siswa sesuai dengan tingkat perkembanganya serta siswa akan senang dalam proses belajar. Akhirnya siswa dapat menguasai pengetahuan, ketrampilan dan sikap secara optimal.

\section{PERKEMBANGAN FISIK ANAK USIA SEKOLAH DASAR}

Perkembagan fisik anak SD adalah perubahan fisik atau pertumbuhan biologi yang dialami oleh anak usia sekolah dasar, yakni umur 6 tahun-12 tahun. Menurut Seifert dan Hoffnung ( 1994 ), perkembangan fisik meliputi perubahan-perubahan dalam tubuh seperti: pertumbuhan otak, sistem syaraf, organorgan indrawi, pertambahan tinggi dan berat, hormon dan lain-lain, dan perubahan-perubahan cara-cara individu dalam menggunakan tubuhnya, serta perubahan dalam kemampuan fisik.

Bagi anak-anak usia sekolah dasar perkembangan fisik merupakan hal yang penting, karena akan mempengaruhi perilaku mereka sehari-hari, termasuk perilaku dalam belajar. Perkembangan fisik yang dimiliki oleh masing-masing anak akan mempengaruhi persepsi mereka pada dirinya sendi dan orang lain. Artinya anak-anak yang memiliki fisik yang edial akan lebih percaya diri dari pada yang kurang ideal. 


\section{Karakteristik Perkembangan Fisik Anak Usia SD}

Pada periode usia sekolah dasar ini perkembangan fisiknya anak sekolah dasar berbeda dengan usia sebelum dan sesudahnya lebih lambat. Hal ini bukan berarti perkembangan anak berhenti, tetapi dapat dikatakan bahwa perkembangan fisik anak itu lebih lambat atau konsisten dibandingkan dengan usia kanak-kanak awal dan usia masuk pubertas.

Selanjutnya karakteristik perkembangan fisik anak usia sekolah dasarakan lebih difokuskan pada: (1) Tinggi dan berat badan, (2) Proporsi tubuh, dan (3) Otak. Di Indonesia tinggi dan berat badan diperkirakan penambahanya berkisar 2,5 - 3,5 kg dan 5-7Cm pertahun (F.A Hodis dalam Wahab 1998/1999: 43) . Demikian juga pendapat (Desmita 2009: 74) mengemukakan bahwa selama masa akhir anak-anak, tinggi bertambah sekitar 5 hingga $6 \%$ dan berat bertambah sekitar $10 \%$ pertahun. Pada usia-usia 6 tahun tinggi rata-rata anak adalah 46 Inci dengan berat $22,5 \mathrm{~kg}$, sedangkan usia 12 tahun tinggi anak mencapai 60 inci, berat badan mencapai 40kg hingga 42,5kg (Mussen,Conger dan Kagan, 1969) .

Berdasarkan uraian di atas peningkatan berat badan anak lebih banyak dari pada panjang badanya. Kaki dan tangan menjadi lebih panjang, dada dan panggul lebih besar. Peningkatan berat badan anak selama ini terjadi terutama karena bertambahnya ukuran sistem rangkadan otot serta ukuran beberapa organ tubuh. Pada saat yang sama secara berangsur-angsur terus bertambah. Pertambahan ini disebabkan karena faktor keturunan dan latihan.

Pertumbuhan fisik pada masa ini, disamping memberikan kemampuan bagi anak-anak untuk berpartisipasi dalam berbagai aktivitas baru tetapi juga dapat menimbulkan permasalahan-permasalahan dan kesulitan-kesulitan secara fisik dan psikologis mereka (Scifert \& Hoffnung, 1994). Kesulitan-kesulitan fisik maksudnya, anak tidak dapat bertindak atau berperilaku secara berani, hal ini disebabkan karena proporsi tubuhnya yang tidak serasi.
Akhirnya orang dewasa ataupun guru mengatakan bahwa mereka tidak sopan. Hal tersebut jelas akan berpengaruh pada psikis anak .

Proporsi/bentuk tubuh anak sekolah dasar , ada yang yang gemuk atau terlihat berbadan besar, ada yang kelihatan kokoh dan kuat, ada juga yang lemah dan tak berotot. Ketiga bentuk tubuh tersebut akan berpengaruh pada perilaku mereka sehari-hari dan juga berpengaruh pada sikap dan psikologis mereka. Anak-anak yang berbadan gemuk biasanya sulit untuk bergerak dan sering diejek oleh teman-temannya sehingga mereka sering merasa rendah diri. Anak-anak yang kokoh dan kuat, mereka cenderung memiliki percaya diri yang tinggi, karena dapat melakukan aktivitas sehari-hari dengan baik. Anak-anak terlihat lemah dan tidak berotot biasanya menjadi ejekan temantemanya, karena kurang mampu beraktivitas seperti yang lain, sehingga mereka juga cenderung kurang percaya diri dan minder.

Selanjutnya untuk pertumbuhan otak anak usia sekolah dasar, dapat dikatakan ukuran menyamai dengan orang dewasa. Artinya bahwa pertumbuhan otak anak mendekati sempurna. Penambahan ukuran otak terjadi karena adanya penambahan jumlah dan ukuran dari ujung- ujung syaraf yang terdapat dalam dan diantara wilayah otak. Disamping itu karena adanya peningkatan melinasi (suatu proses tersekatnya sel-sel syaraf oleh lapisan lemak sehingga meningkatkan kecepatan jalur informasi melalui sistem syaraf). Ujung-ujung syaraf ini terus tumbuh hingga remaja.

Terkait dengan pernyataan tersebut, untuk mencapai kesempurnaan pertumbuhan otak, anak-anak perlu terpenuhi kebutuhan nutrisinya. Tetapi untuk perkembangan otaknya tidak hanya nutrisi saja, melainkan interaksi dengan lingkungan yang berkualitas sangat diperlukan. Seperti dikatakan dalam hasil penelitian Sperry (dalam Wahab, 1998/1999: 48) mengemukakan bahwa konstruksi jaringan otak itu hanya akan hidup bila diprogram melalui rangsangan. Tanpa dirangsang atau digunakan, otak manusia itu tidak akan berkembang. Karena pertumbuhan otak itu memiliki 
keterbatasan waktu, maka rangsangan otak di usia dini sangat penting. Penundaan yang terjadi membuat otak itu tetap tertutup sehingga tidak dapat menerima program-program yang baru.

\section{PERKEMBANGAN MOTORIK ANAK USIA SEKOLAH DASAR}

Perkembangan motorik, sering juga disebut dengan keterampilan motorik. Keterampilan motorik adalah gerakan-gerakan tubuh atau bagian-bagian tubuh yang disengaja, otomatis, cepat dan akurat (Desmita: 2007; 97 ). Gerakan-gerakan yang dilakukan oleh anakanak, termasuk anak sekolah dasar merupakan koordinasi dari beratus-ratus otot yang rumit. Keterampilan motorik dapat dikelompokan menurut ukuran otot-otot dan bagian-bagian badan yang terkait, yaitu keterampilan motorik kasar dan motorik halus. Motorik kasar meliputi keterampilan otot-otot besar lengan, kaki dan batang tubuh, seperti berjalan, melompat, berlari. Sedangkan keterampilan motorik halus meliputi otot-otot kecil yang ada diseluruh tubuh, seperti menyentuh dan memegang.

Keterampilan motorik untuk anak sekolah dasar, seiring dengan pertumbuhan fisiknya mereka sudah mampu mengendalikan dirinya untuk melakukan keterampilan-keterampilan motorik yang lebih terkoordinir. Mereka sudah mampu melakukan keterampilan motorik kasar seperti melempar bola, menagkap bola, berlari, berdiri di atas satu kaki, melompat, mengendarai sepeda dan berenang. Mereka juga sudah mampu melakukan motorik halus, seperti menulis, menggambar dan menyulam atau menjahit.

Keterampilan motorik bagi anak sekolah dasar merupakan suatu aktivitas yang menyenangkan. Hal ini disebabkan otot-otot mereka itu mulai menemukan fungsinya atau berkembang, sehingga mereka tidak dapat duduk diam dalam waktu yang lama. Hal ini sesuai dengan pendapat Wahab (1998/1999 :49) mengemukakan bahwa; anak-anak SD juga lebih mampu mengendalikan tubuhnya sehingga dapat duduk dan memperhatikan sesuatu lebih lama. Namun perlu diingat bahwa mereka masih jauh dari memiliki kematangan fisik dan mereka masih perlu aktif. Anak-anak SD akan lebih tersiksa kalau harus duduk dan memperhatikan guru dengan waktu yang lama. Mereka lebih senang berlari, berlompat atau bermain sepeda. Artinya anak-anak usia SD masih lebih senang melakukan berbagai aktivitas fisik dari pada berdiam diri.

\section{PERKEMBANGAN PERSEPTUAL ANAK USIA SEKOLAH DASAR}

Aktivitas perseptual pada dasarnya merupakan proses pengenalan anak terhadap lingkungannya. Semua informasi tentang lingkungan sampai kepada individu melalui alat-alat indra yang kemudian diteruskan melalui syaraf sensoris ke bagian otak. Informasi tentang obyek penglihatan diterima oleh indra mata, informasi tentang obyek pendengaran diperoleh melalui indra telinga, obyak sentuhan melalui kulit, obyek penciuman melalui hidung. Tanpa penglihatan, pendengaran, penciuman dan indra-indra lainnya, oleh manusia akan terasing dari dunia yang ada disekitarnya.

Aktifitas perseptual merupakan suatu proses psikis, yang antara satu aspek dengan aspek yang lain saling berhubungan. Apabila aspek yang satu dengan yang lain memiliki hubungan yang baik, maka membantu siswa dalam pengolahan informasi, begitu pula sebaliknya. Wahab (1999:51) mengemukakan tiga aktivitas perseptual, yaitu sensori persepsi, dan atensi.

Sensasi adalah peristiwa penerimaan informasi oleh indra penerima. Sensasi berlangsung disaat terjadi kontak antara informasi dengan indra penerima. Dengan demikian, dalam sensasi terjadi proses deteksi informasi secara indrawi. Misalnya sensasi pendengaran terjadi disaat ada gelombang-gelombang udara yang bergetar diterima oleh telinga sebelah luar dan diteruskan kebagian syaraf pendengaran. 
Persepsi adalah interprestasi terhadap informasi yang ditangkap oleh indra penerima. Persepsi merupakan proses pengolahan informasi lebih lanjut dari aktivitas sensasi. Misalnya siswa mengetahui kalau yang didengarnya itu suara gurunya menjelaskan, suara musik,suara mobil dan sejenisnya. Dalam prosesnya, sensasi dan persepsi itu mungkin sulit untuk dipisahkan. Artinya kedua proses itu merupakan sesuatu yang berlangsung secara bersamaan.

Atensi merupakan selektivitas terhadap persepsi. Dengan kesadaran siswa/seseorang bisa hanya tertuju kepada suatu objek atau informasi, dengan mengabaikan objek-objek yang lain. Aktivitas atensi ini diharapkan seseorang fokus terhadap informasi yang masuk pada dirinya, sehingga memperoleh pemahaman tentang informasi tersebut.

Dilihat dari keragaman indra penerima informasi, persepsi dapat diklasifikasi kedalam tiga kelompok, yakni persepsi visual atau penglihatan, persepsi pendengaran, dan persepsi-perspsi minor lainnya. Persepsi visual ini di dasarkan pada indra penglihatan mengutamakan peran mata dalam proses perseptual. Anak-anak mengalami ketajaman penlihatan usia 1 sampai 10 tahun. Pada usia 10 tahun inilah puncak dari ketajaman penglihatan pada anak.

Persepsi visual dapat dibedakan menjadi; persepsi konstanitas ukuran artinya kemampuan individu untuk mengenal bahwa setiap objek itu memiliki ukuran yang konstan; persepsi tentang objek atau gambar pokok dan latar, persepsi ini memungkinkan individu menempatkan suatu objek atau gambar yang berada atau tersimpan pada suatu latar yang membingungkan; persepsi keseluruhan dan bagian, persepsi ini merupakan kemampuan untuk membedakan bagian-bagian suatu objek, atau gambar dari keseluruhan; persepsi kedalam, merupakan kemampuan individu untuk mengukur jarak dari posisi tubuh ke suatu objek ; orientasi tilikan ruang, kemampuan penglihatan untuk mengidentifi- kasi, mengenal dan mengukur dimensi ruang; persepsi gerakan, kemampuan memperkirakan dan mengikuti gerakan atau perpindahan suatu objek oleh mata.

Persepsi pendengaran merupakan pengamatan dan penilaian terhadap suara yang diterima oleh indra telinga. Persepsi ini dibagi menjadi; persepsi lokasi pendengaran, yaitu kemampuan individu mendeteksi tempat munculnya sumber suara; persepsi perbedaan yaitu kemampuan individu mendeteksi perbedaan suara-suara yang mirip; persepsi pendengaran utama dan latarnya.

Persepsi minor yang lain, misalnya sentuhan, penciuman, rasa. persepsi sentuhan pada diri anak terus menerus mengalami perkembangan, demikian juga persepsi minor yang lainnya. Persepsi sentuhan ternyata juga membantu individu dalam memahami informasi yang masuk pada dirinya. Demikian juga penciuman dan rasa. Penciuman dan rasa yang sensitif atau tajam juga akan membatu individu untuk memahami informasi yang masuk pada dirinya.

\section{IMPLIKASI PERKEMBANGAN FISIK, MOTORIK, DAN PERSEPTUAL PADA PEMBELAJARAN DI SEKOLAH DASAR.}

Perkembangan fisik motorik dan perseptual pada anak SD terus mengalami penajaman/penyempurnaan. Perkembangan tersebut memiliki keterkaitan satu dengan yang lain. Artinya apabila satu aspek dari perkembangan tersebut mengalami masalah maka akan mempengaruhi aspek yang lain.

Terkait dengan uraian tersebut seorang guru hendaknya benar-benar memberikan perhatian yang cukup terhadap aspek perkembangan fisik, motorik dan perseptual anak. Perhatian disini bukan sekedar untuk kepentingan perkembangan semata, melainkan untuk kepentingan perkembangan dan aktifitas belajar.

Pemahaman guru/pendidik tentang karakteristik perkembangan fisik, motorik dan 
perseptual akhirnya akan membawa implikasi praktis pada proses pembelajaran di Sekolah Dasar. Implikasi-implikasi tersebut khususnya berkenaan dengan perkembangan fisik motorik, dan perkembangan perseptual. Adapun uraikan yang akan disampaikan berkaitan dengan penyelenggaraan pembelajaran secara umum, penyelenggaraan pendidikan olahraga, pemeliharaan nutrisi anak.

\section{Implikasi Pembelajaran Secara Umum di SD}

Anak sekolah dasar sudah memiliki kemampuan untuk mengontrol tubuhnya. Kondisi yang demikian ini membuat mereka dapat memberikan perhatian yang lebih terhadap kegiatan pembelajaran yang sedang berlangsung. Namun perlu diingat dengan bahwa kondisi mereka masih jauh dari matang dan masih terus berkembang. Fisik mereka masih memerlukan banyak gerak untuk kepentingan peningkatan dan pengayaan keterampilan-keterampilan motoriknya maupun untuk pemenuhan kebutuhan akan gerak dan kekurangan mereka. Begitu juga kondisi perkembangan perseptualnya mengalami penajaman dan penghalusan, Aspek-aspek perseptual ini akan berkembang dengan baik kalau diranggsang dan difungsikan melalui interaksi dengan lingkungan.

Dari uraian tersebut seorang guru dituntut untuk menyelenggarakan pembelajaran di sekolah dasar sesuai dengan karakteristik dan kebutuhan fisik anak. Dalam hal ini perlu ada pembelajaran yang hidup, dalam arti memberikan banyak kesempatan kepada anak untuk memfungsikan unsur unsur fisik dan atau perseptualnya. Dengan kata lain, diperlukan suatu pembelajaran yang bersifat langsung. Pembelajaran seperti ini akan memunculkan kegemaran anak untuk belajar dan dapat mengembangkan fisik, motorik dan perseptual anak, serta dapat berdampak positif pada perkembangan kognisi, kreativitas dan sosialnya.
Kesimpulan dari pernyataan di atas pembelajaran di SD terkait dengan perkembangan fisik, motorik dan perseptual anak diharapkan memiliki karakteristik sebagai berikut : (1) Programnya disusun secara fleksibel dan tidak kaku serta memperhatikan perbedaan individual anak ; (2) tidak dilakukan secara monoton dan verbalistik, tetapi disajikan secara variatif melalui banyak aktivitas seperti eksperimen, praktek, observasi langsung, permainan dan sejenisnya; dan (3) melibatkan penggunaan berbagai media dan sumber belajar sehingga memungkinkan anak terlibat secara penuh dengan menggunakan berbagai proses mental dan perseptual.

\section{Implikasi Bagi Penyelenggaraan Pendidikan Olahraga.}

Program pendidikan olahraga yang rutin dan yang teratur sangat diperlukan bagi anak sekolah dasar. Olahraga ini penting untuk merangsang perkembangan fisik dan perseptual anak. Agar aktifitas olahraga ini memberikan rangsangan yang tepat, maka jenis-jenis kegiatan olahraga yang dipilih hendaknya disesuaikan dengan tahap perkembangan dan kebutuhan fisik anak.

Program olahraga yang cocok diselenggarakan anak sekolah dasar antara lain; (1) memberikan kesempatan kepada anak untuk melakukan kegiatan secara aktif; (2) aktifitas ini dapat diimplementasikan permainanpermainan motorik yang sesuai dengan tahap perkembangan anak. Dengan demikian, diharapkan anak senang berolah raga melalui permainan-permainan yang dirancang sesuai dengan tahap perkembangan dan dunianya.

\section{Implikasi Bagi Pemeliharaan Kesehatan dan Nutrisi anak Sekolah Dasar}

Kesehatan merupakan salah satu faktor utama yang sangat berpengaruh terhadap pertumbuhan fisik anak. Fisik anak yang sehat akan berpengaruh juga pada motorik dan juga 
persptual anak. Anak yang sering sakit-sakitan akan mengalami gangguan dan keterlambatan dalam pertumbuhan fisik, selanjutnya mempengaruhi motorik dan perseptualnya.

Hal-hal yang perlu diperhatikan dalam pemeliharaan kesehatan dan nutrisi anak sekolah dasar sebagai berikut: (1) kebiasaan berperilaku sehat, (2) adanya keteladanan dari pendidik, (3) memberikan makanan dengan gizi yang seimbang. Penanaman kebiasaan berperilaku sehat hendaknya dilakukan secara menyeluruh mulai dari kebersihan pakaian dan tubuh, kebersihan makanan, pemeliharaan kebersihan lingkungan sekitar, serta mendisiplin diri untuk tidak membuang sampah sembarangan.

Hal lain yang perlu diperhatikan dalam penyelenggaraan pendidikan di SD adalh unsur keteladanan dari pihak pendidik/guru. Unsur keteladanan ini akan merupakan suatu upaya pengkondisian anak kearah berperilaku hidup sehat. Kiranya sangat sulit bagi kita sebagai seorang pendidik/guru menganjurkan anak berperilaku hidup sehat, sementara kita sendiri telah menampilkan cara berperilaku yang dimaksud.

Memberikan makanan yang memenuhi gizi yang seimbang merupakan aspek penting dalam perkembangan fisik, motorik, dan perseptual anak. Makanan ini dikenal di Indonesia, makanan yangmemenuhi syarat empatsehatlimasempurna,yaitumakananyang mengandung karbohidrat, protein, mineral, vitamin, dan susu. Jika anak kekurangan gizi, maka perkembangan fisiknya akan terlambat, begitu juga perkembangan fisiknya akan terlambat, begitu juga perkembangan fisik, motorik dan perseptualnya.

Beberapa upaya yang dapat ditempuh sekolah diantaranya: (1) melakukan pemeriksaan kesehatan secara rutin, (2) menciptakan lingkungan sekolah yang sehat, (3) melakukan pembinaan tentang kesehatan terhadap para pedagang makanan yang ada disekitar sekolah, dan (4) menjalin kerjasama dengan orang tua untuk sama-sama membudayakan perilaku hidup sehat. Kegiatan-kegiatan tersebut hendaknya dilaksanakan secara terencana, periodik, dan sistematis.

\section{PENUTUP}

Perkembangan fisik, motorik dan perseptual pada anak SD, ini saling berkaitan satu dengan yang lain. Perkembangan fisik itu meliputi berat, berat badan, dan sistem syarat yang lain, perkembangan motorik itu berhubungan dengan ketrampilan gerak. Sedangkan perkembangan perseptual merupakan proses pengenalan anak terhadap lingkungan.

Karakteristik perkembangan di atas hendaknya dipahami oleh guru/ pendidik. Harapanya para guru dapat melaksanakan proses pembelajaran di SD sesuai dengan tingkat dan ciri khas dari perkembangannya. Akhirnya anak menjadi senang, dan termotivasi untuk belajar, sehingga tujuan yang diharapkan dapat tercapai.

Implikasi pembelajaran secara umum yang sesuai dengan perkembagan fisik, motorik dan perseptual anak adalah dengan memberikan kesempatan untuk memfungsikan unsur-unsur fisik, motorik dan perseptualnya. Misalnya memberikan pengalaman secara langsung, pembelajaran melalui permainan, dan pembelajaran yang dapat melibatkan aspek perseptual, anak dapat memfungsikan penglihatannya, pendengaran, dan indra yang lain untuk menerima pelajaran.

\section{DAFTAR RUJUKAN}

Desmita. 2007. Psikologi Perkembangan. Bandung: PT Remaja Rosdakarya.

Hurlock, E.B. 1980. Developmental Psychology. 5 th Ed. New york : McGrow - Hill, Inc.

Mussen, P.H. dan Kagan, J.J. 1969. Child Development and Personality, 5 th. Ed. New York : Harper and Row Publisher

Seifert, K.L. dan Hoffnung. R.j. 1994. Child and Adolecen Development. 2 nd Ed. Boston : Houghton Mifflin Company. 
Wahab Rochmat. 1999. Perkembangan Dan Belajar Peserta Didik. Jakarta : Depdikbud Dirjendikti Proyek Pendidikan Guru Sekolah Dasar

Undang - undang RI No. 20 Tahun 2003 tentang Sistem Pendidikan Nasional. Sistem Informasi Pendidikan dan Dunia Kerja ( Sindiker ) . (Online), (Http : // sindiker.dikti.go.id/dok/uu 20 - 2003sisdiknas.pdf) diakses pada November 2016. 